\title{
PENGARUH IKLAN HERITAGE TERHADAP BRAND AWARENES, BRAND TRUST, DAN INTENSI PEMBELIAN
}

\section{Happy Sandra' \\ Jony Oktavian Haryanto ${ }^{2}$ \\ Universitas Kristen Satya Wacana, email: jonyharyanto@yahoo.com}

\begin{abstract}
This study is aimed to determine how the influence of heritage advertising, brand awareness and brand trust in creating the intention to buy. This study took 130 respondents and using purposive sampling method. Data analysis techniques used confirmatory factor analysis and structural equation modeling with software LISREL 8.80. The results showed that heritage ads significantly influence brand awareness but not for brand trust and intention to buy. On the other hand, brand awareness significantly influences brand trust as well as intention to buy. Furthermore, brand trust significantly influences intention to buy. Thus, a service provider needs to develop heritage advertising as its function to develop brand awareness which finally create intention to buy. A service provider has to maintain and develop brand awareness because it will create brand trust and intention to buy.
\end{abstract}

Keywords: heritage ads, brand awareness, brand trust, intention to buy.

\section{PENDAHULUAN}

Komunikasi pemasaran sangat penting dalam menstimuli seseorang supaya sadar akan keberadaan merek dan mendorong seseorang untuk melakukan pembelian. Dalam pertumbuhan ekonomi, promosi pemasaran menjadi sangat penting, sebab awal keberhasilan brand akan timbul dari perlakuan promosi yang bagus (http://suaramerdeka.com/2010). Promosi pemasaran dapat dilakukan dengan menggunakan banyak media seperti koran, majalah, tabloid, radio, televisi dan billboard. Dari banyaknya media yang ada, media televisi memiliki potensi untuk menjangkau konsumen sasaran yang lebih luas dibandingkan dengan beberapa media lain. Sehingga Kotler (2005) menyatakan bahwa hal inilah yang menjadi daya tarik bagi para produsen untuk berpromosi melalui media ini.

Hal ini yang mendorong PT Kalbe Farma untuk mempromosikan produknya melalui media televisi. Media televisi mampu menimbulkan dampak yang kuat terhadap konsumen, yaitu melalui indera penglihatan dan indera pendengaran sehingga kreatifitas iklan dapat lebih dieksploitasi dan dioptimalkan. Untuk mengkomunikasikan obat batuk Woods, PT Kalbe

\footnotetext{
${ }^{1}$ Alumnus Fakultas Ekonomika dan Bisnis Universitas Kristen Satya Wacana

${ }^{2}$ Staf Pengajar Fakultas Ekonomika dan Bisnis Universitas Kristen Satya Wacana Jl. Diponegoro 52-60 Salatiga 50742
} 
Farma mengusung iklan yang bertemakan brand heritage, dengan tujuan untuk menyampaikan kualitas produk dari obat batuk Woods. Iklan heritage merupakan iklan dimana cara yang ditempuh untuk menyampaikannya, adalah dengan mewarisi produk kepada turunannya untuk terus dikonsumsi (Hutasoit, 2004 :38). Iklan bertemakan heritage ini merupakan salah satu iklan yang tergolong kreatif dan dipercaya oleh sebagian pemasar untuk membangun kepercayaan merek (Brand Trust) akan kualitas produk. Dengan hal tersebut, penulis tertarik untuk melihat apakah dengan iklan heritage ini mampu meningkatkan penjualan suatu produk.

Belakangan ini sudah banyak pemain yang menempatkan produknya sebagai brand heritage. Pemasar melakukan hal ini dengan maksud ingin mengkomunikasikan produknya sebagi produk yang dikenal dan dipercaya dari masa ke masa. Tapi, satu syarat yang pasti harus dimiliki, produk tersebut harus sudah lama dikenal oleh konsumen. Sehingga, konsumen mengetahui bahwa produk tersebut mempunyai kualitas produk yang baik, terbukti masih bertahan sampai sekarang. Pertanyaan menarik yang kemudian muncul adalah apakah iklah heritage tersebut mampu menciptakan kepercayaan konsumen terhadap merek tersebut sehingga akhirnya memunculkan intenso pembelian.

Berdasarkan Latar belakang diatas, maka persoalan penelitian dapat dirumuskan sebagai berikut:

1. Apakah iklan heritage mempunyai pengaruh positif terhadap brand awareness?

2. Apakah iklan heritage mempunyai pengaruh positif terhadap brand trust?

3. Apakah iklan heritage mempunyai pengaruh positif terhadap intensi pembelian?

4. Apakah brand awareness mempunyai pengaruh positif terhadap brand trust?

5. Apakah brand awareness mempunyai pengaruh positif terhadap intensi pembelian?

6. Apakah brand trust mempunyai pengaruh positif terhadap intensi pembelian?

\section{LANDASAN TEORI}

\section{Iklan Heritage}

Kasali (1992) mendefinisikan iklan sebagai segala bentuk pesan yang menawarkan suatu produk yang ditujukan kepada masyarakat lewat suatu media. Di satu pihak iklan dapat dipergunakan untuk membentuk citra produk dalam jangka panjang yang kurang dimiliki oleh bentuk komunikasi pasar lainnya. Sedangkan heritage diartikan sebagai hal yang terkait dengan tradisi baik keluarga (Fournier, 1998; dalam Strizhakova, Coulter, Linda 2008). Selain itu heritage juga dapat diartikan sebagai silsilah (Evans, 1998 dalam McCain dan Ray 2003). Dengan tradisi yang diturunkan keluarga akan membentuk sebuah budaya. (Cross, 2002 dalam Latour, Michael \& Zinkhan, 2008) berpendapat bahwa budaya mampu menyerap asosiasi merek yang kuat dengan nilai-nilai budaya tersebut. Oleh karenanya heritage ataupun budaya sangat berarti dalam membangun ingatan seseorang mengenai merek atau produk. Sehingga iklan heritage dapat diartikan sebagai iklan dimana cara 
yang ditempuh untuk menyampaikannya, adalah dengan mewarisi produk kepada turunannya untuk terus dikonsumsi (Hutasoit, 2004)

Selanjutnya, iklan dengan pesan heritage memiliki pesan yang penting karena dengan adanya iklan heritage tersebut dapat meyakinkan masyarakat bahwa produk tersebut sudah dikenal dan dipercaya dari masa ke masa. Prianto (2004) menyatakan bahwa ada tiga cara yang bisa ditempuh untuk mengenalkan produk sebagai brand heritage, yaitu: (1) Menggunakan orang yang sudah "estabish". Maksudnya, menggunakan endoser yang sudah dikenal oleh khalayak konsumen sebagai orang yang sudah dikenal oleh khalayak konsumen sebagai orang yang kuat untuk mengajak kepada produk yang bersangkutan. (2) Memakai Event seperti lebaran atau perkawinan. (3) Menggunakan kata tradisi.

\section{Brand Awareness}

Aaker (1997) mendefinisikan kesadaran merek sebagai kesanggupan seseorang calon pembeli untuk mengenali atau mengingat kembali suatu merek sebagai bagian dari suatu kategori produk tertentu. Pada masa sekarang ini konsumen cenderung membeli suatu merek yang sudah dikenal, karena dengan membeli merek yang sudah dikenal, mereka merasa aman, terhindar dari berbagai risiko pemakaian dengan asumsi bahwa merek yang sudah dikenal lebih dapat diandalkan. Hal tersebut menunjukan pentingnya brand awareness konsumen bagi perusahaan.

Untuk mencapai kesadaran merek kategori produk perlu ditekankan karena terdapat suatu hubungan yang erat antara kategori produk dengan merek yang dilibatkan. Brand Awareness adalah bagian dari Brand Equity. Peran Brand Awareness dalam Brand Equity tergantung pada tingkatan akan pencapaian kesadaran di benak konsumen. Brand Awareness memiliki empat tingkatan, dimulai dari yang tinggi, yaitu:

\section{Gambar 1}

\section{Piramida "Brand Awareness"}

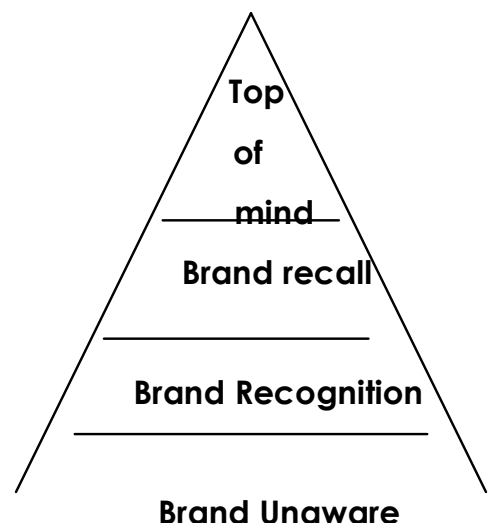

Sumber: Aaker, 1997 
Kesadaran merek terdiri dari beberapa tingkat, yakni dari yang tertinggi sampai yang terendah (Aaker, 1997). Urutannya sebagai berikut: Pertama, Top of mind (puncak pikiran), merek yang pertamakali muncul dalam ingatan apabila seseorang diingatkan pada kategori tertentu. Kedua, Brand recall (pengingatan kembali merek), merek yang diingat atau hafal diluar kepala tetapi tidak muncul sebagai yang pertama. Ketiga, Brand recognation (pengenalan merek), merek yang diketahui tetapi tidak diingat. Keempat, Brand unware (tidak menyadari merek), mereka yang tidak tahu merek..

Pengenalan maupun pengingatan merek akan melibatkan upaya mendapatkan identitas nama dan menghubungannya ke kategori produk. (Durianto dkk, 2003). Agar brand awareness dapat dicapai dan diperbaiki dapat ditempuh beberapa cara berikut: (1) Pesan yang disampaikan harus mudah diingat dan tampil beda dibandingkan dengan lainnya serta harus ada hubungan antara merek dan kategori produknya. (2) Memakai slogan atau jinggle lagu yang menarik sehingga membantu konsumen untuk mengingat merek. (3) Jika produk memiliki simbol, hendaknya simbol yang dipakai dapat dihubungkan dengan mereknya. (4) Perluasan nama merek dapat dipakai agar merek semakin banyak diingat pelanggan. (5) Brand awareness dapat diperkuat dengan memakai suatu isyarat yang sesuai kategory produk, merek, atau keduanya. Melakukan pengulangan untuk meningkatkan pengingatan karena membentuk ingatan lebih sulit dibandingkan membentuk pengenalan.

\section{Brand Trust}

Lau dan Lee (1999) mendefinisikan kepercayaan sebagai kesediaan (willingness) seseorang untuk menggantungkan dirinya pada pihak lain dengan resiko tertentu. Kepercayaan terhadap merek terbentuk dari pengalaman masa lalu dan interaksi sebelumnya (Garbarino dan Johnson, 1999 dalam Karsono, 2008). Selain itu, kepercayaan terbangun karena adanya harapan bahwa pihak lain akan bertindak sesuai dengan kebutuhan dan keinginan konsumen. Ketika seseorang telah mempercayai pihak lain maka mereka yakin bahwa harapan akan terpenuhi dan tak akan lagi ada kekecewaan (Sanner, 1997 dalam Ryan, 2002).

Delgado (2004) dalam Ferrinadewi (2008) mendefinisikan kepercayaan merek sebagai harapan akan kehandalan dan intensi baik merek. Kepercayaan merek merefleksikan 2 hal yakni brand reliability dan brand intentions. Brand reliability atau kehandalan merek mempunyai arti keyakinan konsumen terhadap suatu produk dimana produk tersebut mampu memenuhi nilai yang dijanjikan dan memberikan kepuasan. Brand reliability merupakan hal yang berpengaruh bagi terciptanya kepercayaan terhadap merek. Kemampuan merek memenuhi nilai yang dijanjikannya akan membuat konsumen menaruh rasa yakin mendapatkan apa yang dibutuhkan, dalam hal ini kebutuhan untuk keluar dari perasaan terancamnya. Sedangkan Brand intention dipahami sebagai kepuasan 
pelanggan yang mengakibatkan pelanggan semakin yakin kepada suatu merek sehingga pelanggan akan cenderung memilih merek tersebut dan tidak beralih kepada merek lain.

Lau dan Lee (1999) menyebutkan, ada tiga faktor yang mempengaruhi kepercayaan terhadap merek. Ketiga faktor tersebut adalah merek itu sendiri, perusahaan pembuat merek, dan konsumen. Hubungan ketiga faktor tersebut dengan kepercayaan merek dapat digambarkan sebagai berikut. Pertama, Brand characteristic mempunyai peran yang sangat penting dalam menentukan pengambilan keputusan konsumen untuk mempercayai suatu merek. Karakteristik merek yang berkaitan dengan kepercayaan merek meliputi dapat diramalkan, mempunyai reputasi, dan kompeten. Kedua, Company characteristic yang ada dibalik suatu merek juga dapat mempengaruhi tingkat kepercayaan konsumen terhadap merek tersebut. Pengetahuan konsumen tentang perusahaan yang ada di balik merek suatu produk merupakan dasar awal pemahaman konsumen terhadap merek suatu produk. Karakteristik ini meliputi reputasi suatu perusahaan, motivasi perusahaan yang diinginkan, dan integritas suatu perusahaan. Ketiga, Consumer-brand characteristic merupakan dua kelompok yang saling mempengaruhi. Oleh sebab itu, karakteristik konsumen - merek dapat mempengaruhi kepercayaan terhadap merek. Karakteristik ini meliputi kemiripan antara konsep emosional konsumen dengan kepribadian merek, kesukaan terhadap merek, dan pengalaman terhadap merek.

Evaluasi konsumen terhadap karakteristik produk atau merek sangat penting dalam membentuk keparcayaan. Morgan dan Hunt (1994) menyatakan bahwa, kepercayaan merupakan satu variabel kunci untuk memelihara hubungan jangka panjang pada sebuah merek. Sedangkan Howard (1994) berpandapat kepercayaan konsumen adalah bagaimana pembeli dapat yakin akan keputusan mereka terhadap merek tertentu, apakah produk tersebut dapat memuaskan kebutuhan pembeli atau tidak.

\section{Intensi Pembelian}

Intensi pembelian didefinisikan sebagai sesuatu yang berhubungan dengan rencana konsumen untuk membeli produk tertentu serta berapa banyak unit produk yang dibutuhkan pada periode tertentu (Howard, 1994). Intensi pembelian terbentuk dari sikap konsumen terhadap kualitas produk. Semakin rendah keyakinan konsumen terhadap suatu produk akan menyebabkan menurunnya intensi beli konsumen. Menurut (Assael, 1995) intensi pembelian merupakan minat pembelian ulang yang menunjukkan keinginan pelanggan untuk melakukan pembelian ulang.

Sedangkan (Engel dkk, 1995) berpendapat bahwa minat membeli merupakan suatu kekuatan pendorong atau sebagai motif yang bersifat instrinsik yang mampu mendorong seseorang untuk menaruh perhatian secara spontan, wajar, mudah, tanpa paksaan dan selektif pada suatu produk untuk kemudian mengambil keputusan membeli. Hal yang mendukung konsumen dalam melakukan pembelian didasarkan pada kepuasan konsumen atas suatu produk yang mampu memenuhi harapan dari yang diinginkan konsumen. 
Semakin tinggi tingkat kepuasan konsumen maka tingkat intensi pembelian juga semakin tinggi.

Dalam intensi pembelian terdapat beberapa pengertian menurut Setyawan dan Ihwan (2004) yaitu sebagai berikut:1) Intensi dianggap sebagai sebuah perangkap atau perantara antara faktor-faktor motivasional yang mempengaruhi perilaku. 2) Intensi juga mengindentifikasikan seberapa jauh seorang mempunyai kemauan untuk mencoba. 3) Intensi menunjukkan pengukuran kehendak seseorang. 4) Intensi berhubungan dengan perilaku yang terus menerus.

Intensi pembelian akan berpengaruh terhadap perilaku konsumen. Apabila konsumen sudah mempunyai intensi pembelian maka akan dikembangkan untuk keputusan pembelian atau mengkonsumsi. Hal tersebut didukung dari hasil studi empiris yang sebagian besar menyatakan bahwa intensi pembelian berpengaruh signifikan terhadap perilaku seseorang.

\section{PENGEMBANGAN HIPOTESIS}

\section{Pengaruh iklan heritage terhadap Brand Awareness}

Iklan heritage merupakan cara yang efektif dalam membentuk sikap konsumen (Prianto, 2004). Keberhasilan iklan heritage dinilai dari kesadaran seseorang terhadap merek produk yang diiklankan. Tingkat kesadaran akan merek tinggi, maka promosi dikatakan berhasil (http://suaramerdeka.com/2010) Untuk membentuk kesadaran merek maka dalam mengkomunikasikan suatu produk diperlukan kekreatifan dalam pembuatan iklan. Salah satu hal yang menjadi pembentuk kesadaran seseorang terhadap merek adalah dengan pesan iklan yang berbeda dan cerita yang mudah dipahami (Durianto dkk, 2003).

Leonard (2005) menyatakan bahwa kepercayaan, nilai dan simbol yang dibagi bersama oleh masyarakat dan diteruskan dari satu generasi ke generasi berikutnya akan membentuk sebuah budaya. Seperti halnya iklan heritage dimana cara penyampaian pesan dilakukan dengan mewarisi produk turunan untuk terus dikonsumsi. Pesan iklan heritage dikemas dengan menonjolkan kualitas produk yang terbukti dari masa ke masa. Strategi promosi dengan iklan heritage ditujukan agar konsumen sadar bahwa produk yang sudah lama dan menjadi warisan yang terbukti berkualitas.

Berdasarkan uraian di atas dapat dirumuskan hipotesis penelitian (H1) sebagai berikut: "Semakin bagus iklan heritage, maka semakin tinggi brand awareness".

\section{Pengaruh iklan heritage terhadap Brand Trust}

Ketika seseorang melihat iklan dengan pesan heritage, maka kepercayaan terhadap merek akan terbentuk. Kepercayaan akan merek ini timbul sebagai respon dari seseorang dalam menangkap pesan iklan heritage yang menguraikan bagaimana produk yang diiklankan merupakan produk turunan (Hutasoit,2004) dan masih bertahan sampai sekarang. Ferrinadewi (2008) berpendapat bahwa, seseorang mempercayai suatu merek atau produk didasarkan pada keandalan suatu merek tersebut. 
Respon seseorang terhadap iklan yang mengkomunikasikan produknya dengan produk yang sudah lama di kenal dan sudah terbukti kualitasnya akan memelihara hubungan jangka panjang terhadap sebuah merek (Morgan dan Hunt,1994). Sejalan dengan konsep relationship marketing dapat ditarik kesimpulan bahwa iklan heritage akan berpengaruh terhadap brand trust hal ini disebabkan karena iklan heritage mampu menciptakan suatu hubungan timbal balik yang bernilai tinggi.

Kepercayaan konsumen dapat meningkat jika calon pembeli sudah mendapatkan keterangan yang jelas yang didapat konsumen dari pesan iklan yang ditayangkan televisi secara berulang (Leonard, 2005). Oleh karena itu iklan dengan pesan heritage dibuat dengan model cerita yang sederhana akan tetapi tetap menunjukkan bahwa produk yang diiklankan berkualitas sejak lama dan sudah terbukti kualitasnya dari masa ke masa. Kepercayaan merek yang diakibatkan dari respon seseorang terhadap iklan heritage bersumber dari sebagian besar orang menganggap bahwa produk yang diwarisi atau turun temurun berkualitas tinggi.

Berdasarkan uraian di atas dapat dirumuskan hipotesis penelitian (H2) sebagai berikut: "Semakin bagus iklan heritage, maka semakin tinggi brand trust".

\section{Pengaruh iklan heritage terhadap Intensi Pembelian}

Ketika seseorang mengenal suatu merek melalui periklanan dengan pesan heritage dan mampu menerima pesan yang diiklankan dengan baik, timbul keinginan untuk mencoba dan menggunakan produk yang diiklankan (http:// kompas.com/2010). Keinginan ini timbul akibat respon dari seseorang yang di ungkapkan secara spontan (Peck \& Childers, 2005 dalam Haryanto, 2008) terhadap kebutuhan seseorang untuk mencoba suatu produk. Rusmana (2007) membuktikan bahwa iklan heritage efektif dalam membentuk sikap konsumen.

McCain dan Ray (2003) menyatakan bahwa apa yang menjadi warisan dari keluarga akan berpangaruh terhadap keinginan untuk mewarisi suatu produk tersebut. Hal ini sependapat dengan tujuan dari iklan heritage dimana iklan yang dibentuk, dengan mewarisi produk kepada turunannya untuk terus dikonsumsi. Sedangkan Leonard (2005) mengungkapkan bahwa kepercayaan, nilai dan simbol dari satu generasi ke generasi berikutnya akan membentuk sebuah budaya atau tradisi. Dari iklan heritage yang mengusung tinggi nilai budaya atau tradisi mampu mempengaruhi seseorang untuk merencanakan pembelian, maka pengembangan selanjutnya akan mempengaruhi keputusan beli dan konsumsi (Wibowo, 2009).

Berdasarkan uraian di atas dapat dirumuskan hipotesis penelitian (H3) sebagai berikut: "Semakin bagus iklan heritage, maka semakin tinggi intensi pembelian".

\section{Pengaruh Brand Awareness terhadap Brand Trust}

Kesadaran merek adalah tahap komunikasi paling awal dalam membangun sebuah brand yang kuat (http:// kompas.com/2010). Ketika seseorang sadar akan suatu merek 
maka akan membentuk kepercayaan konsumen terhadap suatu merek. Oleh karena itu pengenalan terhadap suatu merek sangat penting bagi kepercayaan konsumen untuk menilai apakah suatu merek tersebut mempunyai nilai positif bagi konsumen atau tidak (Anderson dan Narus, 2005 dalam Handriana dan Yuniar, 2008).

Upaya pengenalan merek seringkali dilakukan dengan hebat melalui frekuensi komunikasi yang tinggi yang bertujuan agar merek mampu melekat di benak konsumen. Promosi dikatakan berhasil apabila merek yang dikomunikasikan mampu membentuk kesadaran merek yang tinggi atau dengan kata lain dapat disebut sebagai (top of mind) puncak pikiran (Aaker, 1997). Selanjutnya apabila konsumen sadar akan merek yang diiklankan melalui iklan heritage maka, pengembangan selanjutnya adalah pembentukan kepercayaan konsumen terhadap suatu merek. Hal ini akan berlanjut pada loyalitas konsumen terhadap suatu merek (Chouldum, 2004 \& Riana, 2008).

Dalam kehidupan sehari-hari, sering ditemui bahwa sebagian besar orang percaya dan loyal terhadap suatu merek apabila seseorang mempunyai pengalaman yang baik dengan merek tersebut. Orang akan cenderung memilih merek dan percaya terhadap merek yang sudah dikenal sejak lama daripada harus mencoba merek baru yang belum dikenalnya. Karena orang menganggap merek yang dikenalnya terbukti berkualitas. Dengan demikian, sudah menjadi bukti nyata bahwa kesadaran seseorang terhadap suatu merek berpengaruh terhadap kepercayaan seseorang terhadap suatu merek.

Berdasarkan uraian di atas dapat dirumuskan hipotesis penelitian (H4) sebagai berikut: "Semakin tinggi brand awareness, maka semakin tinggi brand trust".

\section{Pengaruh Brand Awareness terhadap Intensi Pembelian}

Ketika kesadaran seseorang akan suatu merek tinggi maka, akan berpengaruh terhadap rencana seseorang untuk membeli suatu produk yang dikenalnya (Howard, 1994). Kesadaran merek atau pengenalan merek didefinisikan sebagai kemampuan seseorang dalam mengidentifikasi dan menguraikan atribut brand, baik dari fisik maupun nonfisik dari suatu merek (http:// kompas.com/2010). Ketika kesadaran akan suatu merek berlanjut ke tahap yang lebih tinggi, yaitu tahap uji coba, maka kemungkinan akan membentuk loyalitas dan pada akhirnya akan menimbulkan pembelian berulang.

Durianto dan Cecilia (2004) dalam Leonard (2005) menyatakan bahwa sikap konsumen terhadap merek akan timbul setelah konsumen mengenal suatu merek atau langsung mendengar pesan iklan yang disampaikan. Ketika pengukuran kesadaran merek dilakukan, maka peran promosi menjadi sangat penting mengingat pengenalan terhadap merek merupakan salah satu fungsi pokok promosi. Jika seseorang tidak sadar (tidak mengenal atau tidak mampu mengidentifikasi), maka sulit bagi seseorang tersebut untuk mempertimbangkan penggunaan brand tersebut. Sehingga preferensi seseorang terhadap suatu merek negatif dan kemungkinan untuk melakukan pembelian juga kecil. Untuk itu brand awareness harus di tingkatkan agar mampu menimbulkan intensi pembelian. 
Sehingga dapat disimpulkan bahwa kerentanan perpindahan pelanggan dapat ditekan dengan meningkatkan brand awareness.

Berdasarkan uraian di atas dapat dirumuskan hipotesis penelitian (H5) sebagai berikut: "Semakin tinggi brand awareness, maka semakin tinggi intensi pembelian".

\section{Pengaruh Brand Trust terhadap Intensi Pembelian}

Konsep Trust dipandang sebagai dasar dalam hubungan dengan konsumen dan trust merupakan atribut terpenting yang dimiliki oleh merek. Oleh karena itu kepercayaan merupakan hal terpenting yang dimiliki merek, maka kepercayaan digunakan untuk menjaga hubungan jangka panjang terhadap suatu merek (Morgan dan Hunt, 1994) agar terbentuk intensi pembelian.

Dalam penelitiannya, Howard (1994) menyatakan bahwa kepercayaan konsumen adalah bagaimana pembeli dapat yakin akan keputusan seseorang terhadap merek tertentu, apakah produk tersebut dapat memuaskan kebutuhan pembeli atau tidak. Kepercayaan atau keyakinan merupakan tingkat kepastian konsumen yang menyatakan penilaiannya terhadap suatu produk atau merek. Jika penilaian akan suatu produk atau merek baik atau dengan kata lain konsumen yakin terhadap suatu produk atau merek tersebut maka konsumen tidak segan-segan untuk melakukan pembelian.

Kepercayaan terhadap suatu merek terbentuk karena adanya keandalan produk, reputasi, pengalaman terhadap suatu produk yang baik, dan kualitas dari produk (Lau dan Lee, 1999). Apabila seseorang yakin terhadap suatu produk yang dinilainya maka, akan membentuk intensi pembelian terhadap produk tersebut. Ferrinadewi (2008) berpendapat bahwa intensi pembelian terbentuk dari sikap konsumen terhadap kualitas produk. Dengan demikian, sudah menjadi bukti nyata bahwa kepercayaan seseorang terhadap suatu merek berpengaruh terhadap intensi pembelian suatu produk.

Berdasarkan uraian di atas dapat dirumuskan hipotesis penelitian (H6) sebagai berikut: "Semakin tinggi brand trust, maka semakin tinggi intensi pembelian".

\section{Model penelitian}

Model penelitian yang menggambarkan keseluruhan pengaruh antara iklan heritage terhadap Brand awareness, Brand trust dan intensi beli adalah: 


\section{Gambar 2}

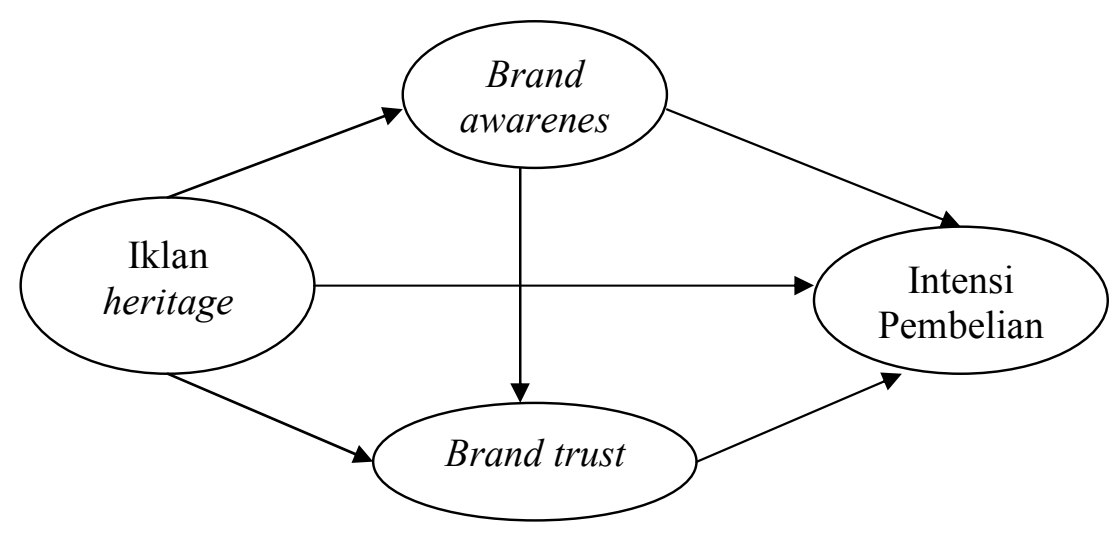

\section{METODE PENELITIAN}

Teknik pengambilan sampel adalah purposive sampling yang merupakan teknik pengambilan sampel dimana elemen dari populasi dipilih dengan maksud tertentu berdasarkan pertimbangan peneliti (Malhotra, 1999:35). Adapun pertimbangan untuk memilih sampel dengan metode purposive sampling ini adalah masyarakat Salatiga yang pernah melihat iklan obat batuk woods versi "Keluarga Katon" di media televisi.

Besarnya ukuran sampel dalam penelitian dengan structural equation modeling minimum 100 sampel atau 5 kali jumlah parameter yang diestimasi (Hair et al., 1998). Untuk itu sampel yang ditetapkan peneliti sebesar 130 orang dengan mempertimbangkan model penelitian yang diestimasi.

Teknik pengumpulan data dalam penelitian ini dilakukan melalui kuisioner dengan menggunakan skala Likert. Dengan membuat suatu daftar pertayaan yang akan diisi oleh responden untuk memperoleh data berupa jawaban yang akan dianalisis. Dalam penelitian ini, instrumen untuk mengukur variabel penelitian menggunakan skala Likert 4 poin (1-4) skala.

Untuk menguji hipotesis penelitian digunakan alat analisis Structural Equation Model (SEM)dengan bantuan program LISREL versi 8.80. SEM merupakan teknik multivariate yang mengkombinasikan aspek regresi berganda dan analisis faktor untuk mengestimasi serangkaian hubungan ketergantungan secara simultan (Hair et.at.,1998) 


\section{HASIL DAN PEMBAHASAN}

Berikut ini akan disajikan hasil pengolahan data dengan menggunakan LISREL 8.8 yang menunjukkan nilai untuk digunakan dalam pengujian hipotesis yang telah dibuat sebelumnya. Pengujian hipotesis ini akan dilakukan dengan syarat tingkat signifikansi sebesar 0.05 atau 5\% dan nilai kritis † sebesar > 1.645. berikut ini ditampilkan Tabel 2 yang berisi nilai hasil estimasi atas hubungan kausal yang akan diuji dan Tabel 4 yang menyajikan hasil pengujian hipotesis dengan melihat nilai t masing-masing hubungan. 
Tabel 2

Persamaan Model Struktural

\begin{tabular}{|c|c|}
\hline No & Persamaan \\
\hline 1 & $\begin{array}{cc}\text { AWARENESS }= & 0.67 * \mathrm{HERITAGE}, \text { Errorvar. }=0.55, \mathrm{R}^{2}=0.45 \\
(0.15) & (0.21) \\
4.63 & 2.63\end{array}$ \\
\hline 2 & $\begin{array}{ccc}\text { TRUST }= & 0.68^{*} \text { AWARENESS }+0.18^{*} \text { HERITAGE, Errorvar. }=0.34, R^{2}=0.66 \\
(0.19) & (0.11) & (0.13) \\
3.53 & 1.60 & 2.61\end{array}$ \\
\hline 3 & $\begin{array}{l}\text { INTENSI BELI }=0.46^{*} \text { AWARENESS }+0.52^{*} \text { TRUST }-0.12 * \text { HERITAGE, Errorvar. }=0.26, R^{2} \\
=0.74 \\
\begin{array}{cccc}(0.17) & (0.16) & (0.10) & (0.063) \\
2.77 & 3.27 & -1.16 & 4.12\end{array}\end{array}$ \\
\hline
\end{tabular}

Setelah diketahui parameter dalam persamaan tersebut, uji hipotesis dapat dilaksanakan dengan hasil seperti Tabel 3 berikut ini:

Tabel 3

Hasil Pengujian Hubungan Model Struktural

\begin{tabular}{|c|l|c|c|}
\hline Hipotesis & \multicolumn{1}{|c|}{ Pernyataan Hipotesis } & Nilai $\dagger$ & \multicolumn{1}{|c|}{ Keterangan } \\
\hline H1 & $\begin{array}{l}\text { Semakin bagus iklan heritage, maka semakin } \\
\text { tinggi brand awareness }\end{array}$ & 4.63 & Didukung data \\
\hline H2 & $\begin{array}{l}\text { Semakin bagus iklan heritage, maka semakin } \\
\text { tinggi brand trust }\end{array}$ & 1.60 & $\begin{array}{l}\text { Tidak didukung } \\
\text { data }\end{array}$ \\
\hline H3 & $\begin{array}{l}\text { Semakin bagus iklan heritage, maka semakin } \\
\text { tinggi intensi pembelian }\end{array}$ & -1.16 & $\begin{array}{l}\text { Tidak didukung } \\
\text { data }\end{array}$ \\
\hline H4 & $\begin{array}{l}\text { Semakin tinggi brand awareness , maka } \\
\text { semakin tinggi brand trust }\end{array}$ & 3.53 & Didukung data \\
\hline H5 & $\begin{array}{l}\text { Semakin tinggi brand awareness , maka } \\
\text { semakin tinggi intensi pembelian }\end{array}$ & 2.77 & Didukung data \\
\hline H6 & $\begin{array}{l}\text { Semakin tinggi brand trust , maka semakin } \\
\text { tinggi intensi pembelian }\end{array}$ & 3.27 & Didukung data \\
\hline
\end{tabular}

PEMBAHASAN

\section{Pengaruh iklan heritage terhadap Brand Awareness}

Dari hasil analisis diatas dapat disimpulkan bahwa iklan heritage berpengaruh signifkan terhadap Brand awareness produk obat batuk Woods. Iklan heritage atau iklan produk turun temurun ternyata cukup kuat dalam membentuk kesadaran konsumen terhadap merek. Hal ini disebabkan responden beranggapan bahwa iklan yang disampaikan dalam iklan Woods di televisi mudah dimengerti dalam memberikan informasi bahwa obat batuk Woods merupakan obat batuk keluarga yang diturunkan dari masa ke masa.. Penyampaian informasi dalam iklan heritage obat batuk Woods di televisi dirasakan telah berhasil membentuk kesadaran konsumen untuk mengingat produk obat batuk Woods. Kejelasan informasi dari suatu iklan akan mempengaruhi brand awareness seseorang. Hal ini juga berlaku dalam penelitian ini, yaitu bahwa iklan heritage atau iklan yang 
menunjukkan produk turun temurun dari obat batuk Woods mampu membentuk kesadaran merek obat batuk Woods.

Dengan iklan heritage obat batuk Woods yang disampaikan cukup jelas dan diperkuat dengan manfaat-manfaat yang ada dari obat batuk Woods, akan membuat informasi iklan yang disampaikan efektif. Penyampaian informasi atau pesan iklan yang disajikan secara jelas dan menarik dapat membantu perhatian konsumen, jika perhatian konsumen terhadap iklan heritage tersebut sudah didapatkan, maka tidak menutup kemungkinan produk yang diiklankan tersebut melekat pada benak konsumen.

\section{Pengaruh iklan heritage terhadap Brand Trust}

Dari hasil analisis diatas dapat disimpulkan bahwa iklan heritage memiliki pengaruh yang tidak signifikan terhadap brand trust. Iklan heritage yang disampaikan obat batuk Woods yaitu produk yang turun temurun, produk berkualitas, dan terbukti sejak dulu. Iklan ini dibuat dengan cara menonjolkan bahwa obat batuk Woods merupakan obat batuk yang merupakan produk turun temurun dan berkualitas dari masa ke masa, sehingga diharapkan dapat memberikan kepercayaan dalam iklan ini, namun pada kenyataannya responden merasa tidak memperhatikan pesan maupun cerita dari iklan tersebut.

Hal ini dapat terjadi karena saat ini perkembangan tentang penelitian obat obatan sudah semakin canggih dan hal ini menyebabkan responden lebih mempercayai kemampuan obat batuk yang baru. Karena responden mempersepsikan bahwa obat batuk Woods merupakan obat batuk yang sudah lahir sejak lama dan menganggap kualitas dari obat batuk Woods kalah dengan obat batuk di jaman sekarang yang sudah diproses dengan alat yang canggih. Hal ini juga didukung dengan perkembangan jaman dimana konsumen modern akan lebih percaya terhadap kecanggihan teknologi yang ada sehingga konsumen modern akan melupakan produk obat batuk Woods yang sudah lahir sejak lama.

Dari alasan diatas seharusnya dapat diperhatikan oleh PT Kalbe Farma bahwa dalam proses penyampaian iklan seharusnya PT Kalbe Farma tetap harus menunjukkan dalam iklannya, walaupun produk obat batuk Woods merupakan obat batuk yang sudah lama akan tetapi proses pembuatan obat batuk Woods selalu mengikuti perkembangan jaman yang ada sehingga kualitas produk obat batuk Woods tidak terkalahkan dengan obat batuk jaman modern.

\section{Pengaruh iklan heritage terhadap Intensi Pembelian}

Dari hasil analisis diatas dapat disimpulkan bahwa iklan heritage tidak memiliki pengaruh positif terhadap intensi membeli. Iklan produk turun temurun yang dikemas dengan menonjolkan cerita keluarga dan menunjukkan bahwa produk tersebut mempunyai kualitas yang tinggi karena dikonsumi dari masa ke masa, diharapkan mampu mempengaruhi intensi pembelian, ternyata hal tersebut tidak cukup kuat untuk mempengaruhi konsumen dalam membeli obat batuk Woods. 
Dari hasil wawancara yang telah dilakukan peneliti, kebanyakan responden mengaku bahwa iklan heritage dari obat batuk Woods tidak mempengaruhi intensi pembelian. Responden juga menyatakan bahwa responden lebih tertarik dengan obat batuk Komix dimana dalam pengiklanan obat batuk Komix dirasa lebih menarik dari iklan obat batuk Woods. Dimana dalam pengiklanannya obat komik mempunyai slogan "Batuk di Komix Saja" hal itulah yang membuat banyak responden yakin bahwa apabila sedang batuk minum komix pasti akan sembuh sehingga akan berpengaruh terhadap intnsi pembelian. Persepsi terhadap iklan diukur dalam afektif penerima pesan yang menilai baik-tidak baik, suka-tidak suka, menarik-tidak menarik, kreatif-tidak kreatif, informati-tidak informatif (Shimp, 2003). Apabila persepsi seseorang terhadap suatu promosi itu negative maka tidak ada rasa suka atau simpatik terhadap promosi yang disampaikan sehingga tidak akan meningkat ke intensi pembelian.

\section{Pengaruh Brand Awareness terhadap Brand Trust}

Dari hasil analisis diatas dapat disimpulkan bahwa brand awareness mempunyai pengaruh positif terhadap brand trust. Kesadaran konsumen terhadap suatu merek sangatlah penting dalam membentuk kepercayaan konsumen terhadap suatu merek. Konsumen yang sadar terhadap terhadap suatu merek akan selalu mengingat merek tersebut dan produk tersebut akan selalu melekat dibenak konsumen. Oleh karena itu pemasar harus bisa menciptakan kesadaran seseorang terhadap suatu merek yang diiklankan. Menciptakan kesadaran target market adalah tahap komunikasi paling awal dalam membangun brand yang kuat (http://suaramerdeka.com/2010). Hal ini juga berlaku terhadap penelitian ini, yaitu bahwa dengan kesadaran merek terhadap obat batuk Woods akan membantu konsumen untuk lebih mempercayai merek obat batuk Woods karena konsumen akan percaya terhadap produk yang sudah dikenalnya dari pada produk yang belum dikenal.

\section{Pengaruh Brand Awareness terhadap Intensi Pembelian}

Dari hasil analisis diatas dapat disimpulkan bahwa brand awareness mempunyai pengaruh yang signifikan terhadap intensi pembelian. Pengingatan konsumen terhadap suatu merek ternyata cukup kuat untuk membangkitkan intensi pembelian seseorang. Hal ini terjadai karena kesadaran terhadap suatu merek yang positif akan berlanjut sampai ke tindakan seseorang dalam hal ini mampu membangkitkan intensi beli. Konsumen cenderung membeli suatu merek yang sudah dikenal, karena dengan membeli merek yang sudah dikenal, mereka merasa aman, terhindar dari berbagai risiko pemakaian dengan asumsi bahwa merek yang sudah dikenal lebih dapat diandalkan. Hal ini juga berlaku pada penelitian ini, yaitu konsumen yang sadar terhadap obat batuk Woods akan selalu mengingat obat batuk Woods dan akhirnya akan berlanjut ke dalam rencana untuk membeli obat batuk Woods disaat sakit batuk. 


\section{Pengaruh Brand Trust terhadap Intensi Pembelian}

Dari analisis diatas dapat disimpulkan bahwa brand trust memiliki pengaruh yang positif terhadap intensi pembelian. Keandalan, kualitas dan reputasi dari suatu produk ternyta mampu mendorong keinginan untuk melakukan pembelian. Konsumen yang percaya terhadap suatu merek akan cenderung memiliki keinginan untuk melakukan pembelian. Karena dengan percaya terhadap suatu merek., berarti konsumen merasa puas dengan apa yang diberikan produk tersebut. Hal ini juga berlaku pada penelitian ini, yaitu konsumen yang percaya terhadap obat batuk Woods berarti konsumen tersebut puas dengan apa yang diberikan obat batuk Woods dan akhirnya akan mendorong keinginan untuk membeli obat batuk Woods.

\section{SIMPULAN}

Berdasarkan analisis dan bahasan analisis yang telah diuraikan terdahulu, maka dapat ditarik kesimpulan sebagai berikut:

1. Iklan heritage dalam iklan obat batuk Woods berpengaruh positif terhadap Brand awareness obat batuk Woods. Hasil ini mendukung hipotesis awal penulis yang diajukan dalam penelitian ini.

2. Iklan heritage dalam iklan obat batuk Woods tidak berpengaruh positif terhadap Brand trust obat batuk Woods. Hasil ini tidak mendukung hipotesis awal penulis yang diajukan dalam penelitian ini.

3. Iklan heritage dalam iklan obat batuk Woods tidak berpengaruh positif terhadap Intensi pembelian obat batuk Woods. Hasil ini tidak mendukung hipotesis awal penulis yang diajukan dalam penelitian ini.

4. Brand Awareness obat batuk Woods berpengaruh positif terhadap Brand Trust obat batuk Woods. Hasil ini mendukung hipotesis awal penulis yang diajukan dalam penelitian ini.

5. Brand Awareness obat batuk Woods berpengaruh positif terhadap Intensi beli obat batuk Woods. Hasil ini mendukung hipotesis awal penulis yang diajukan dalam penelitian ini.

6. Brand Trust dalam iklan obat batuk Woods berpengaruh positif terhadap Intensi pembelian obat batuk Woods. Hasil ini mendukung hipotesis awal penulis yang diajukan dalam penelitian ini.

\section{Implikasi Manajerial}

1. Dapat dijadikan masukan bagi PT. Kalbe Farma, bahwa iklan heritage dalam iklan obat batuk Woods berpengaruh secara signifikan terhadap Brand awareness obat batuk Woods. Perusahaan harus tetap mempertahankan dan meningkatkan strategi 
penyampaian pesan dalam iklan obat batuk Woods yang jelas dan mudah dimengerti dalam memberikan informasi dan diperkuat dengan manfaat-manfaat yang ada dari obat batuk Woods, sehingga pada akhirnya dapat membangun kesadaran merek terhadap obat batuk Woods.

2. Dapat dijadikan masukan bagi PT. Kalbe Farma, bahwa iklan heritage obat batuk Woods tidak berpengaruh signifikan terhadap brand trust obat batuk Woods. Perusahaan harus lebih memperhatikan dalam pemilihan alur cerita, karena hal tersebut sangat penting dalam proses penyampaian pesan iklan untuk membentuk persepsi positif seorang terhadap produk yang diiklankan. Pemasar hendaknya menggunakan cerita iklan yang menonjolkan bahwa produk obat batuk Woods tidak kalah dengan produk obat batuk di jaman modern, yaitu dengan menceritakan bahwa produk Woods merupakan produk lama akan tetapi pengolahannya tetap menggunakan tekhnologi canggih sehingga dari dulu sampai sekarang tetap berkualitas. Dengan cerita iklan dengan menonjolkan proses pembuatan dengan teknologi canggih bisa menambah kepercayaan konsumen pada produk obat batuk Woods.

3. Dapat dijadikan masukan bagi PT. Kalbe Farma, bahwa iklan heritage obat batuk Woods tidak berpengaruh signifikan terhadap Intensi pembelian obat batuk Woods. Perusahaan harus lebih memperhatikan penyampaian pesan iklan dalam iklan obat batuk Woods yang kreatif dan menarik. Pemasar seharusnya menggunakan tampilan iklan yang mampu menarik perhatian khalayak yaitu dengan dukungan bintang iklan yang populer dan juga pemberian slogan yang mudah dipahami dan diingat khalayak. Hal ini penting agar kesan yang timbul dalam diri pemirsa terhadap iklan tersebut mampu menimbulkan rasa menyenangkan, yang membuat pemirsa tersentuh emosinya, dan mengerti pesan iklan yang disampaikan sehingga mampu membentuk keinginan konsumen untuk membeli obat batuk Woods. Intensi pembelian akan terbentuk apabila persepsi konsumen terhadap suatu iklan tersebut positif.

4. Dapat dijadikan masukan bagi PT. Kalbe Farma, bahwa Brand Awareness obat batuk Woods berpengaruh signifikan terhadap Brand Trust obat batuk Woods. Pemasar harus menciptakan kesadaran merek terhadap suatu produk dan terus menerus mengingatkan konsumen akan obat batuk Woods. Hal ini dapat dilakukan dengan frekuensi munculnya iklan obat batuk Woods yang tinggi. Dengan frekuensi munculnya iklan yang tinggi akan menstimuli seseorang untuk lebih cepat sadar terhadap obat batuk Woods. Mengingat kesadaran merek merupakan faktor penting untuk membangun merek dalam jangka panjang, maka dalam proses pengiklanan pemasar harus benar-benar memperhatikan hal ini. Konsumen akan mempercayai produk apabila konsumen tersebut sudah sadar dan mengenal merek.

5. Dapat dijadikan masukan bagi PT. Kalbe Farma, bahwa Brand Awareness obat batuk Woods berpengaruh signifikan terhadap Intensi pembelian obat batuk Woods. Berkaitan 
dengan kesadaran merek mampu membangun intensi pembelian, maka pemasar harus gencar dalam membangun kesadaran merek seseorang. Sering kali seseorang yang mengenal merek dengan baik, akan timbul keinginan untuk mencoba ataupun menggunakannya. Strategi dalam menciptakan kesadaran merek selain dengan frekuensi komunikasi yang tinggi dapat juga dilakukan dengan mamasukkan keunggulan produk tersebut. Disini obat batuk Woods mempunyai keunggulan dimana obat batuk Woods mempunyai dua jenis produk yaitu untuk batuk kering dan batuk berdahak. Keunggulan inilah yang menjadi daya tarik untuk mempengaruhi seseorang adar terhadap produk tersebut dan akan berdampak pada intensi pembelian obat batuk Woods.

6. Dapat dijadikan masukan bagi PT. Kalbe Farma, bahwa Brand Trust obat batuk Woods berpengaruh signifikan terhadap Intensi pembelian obat batuk Woods. Kepercayaan konsumen terhadap suatu merek sangatlah penting dalam membentuk intensi pembelian. Kepercayaan konsumen tersebut akan terbentuk apabila produk tersebut andal, mampu memenuhi nilai yang dijanjikan dan mempunyai reputasi serta kualitas yang baik. Oleh kerena itu obat batuk Woods harus selalu mempertahankan kualitas produknya dan harus mampu membuktikan bahwa obat batuk Woods merupakan obat batuk yang terbukti dari masa ke masa. Berhubung kepercayaan terhadap suatu merek penting dalam membentuk intensi pembelian, maka dalam penyampaian iklan pemasar harus menepati janji yang disampaikan. Karena apabila seseorang puas terhadap apa yang diharapkan maka orang tersebut akan mempercayai produk tersebut dan akhirnya menginginkan untuk membeli produk tersebut.

\section{Keterbatasan Penelitian}

1. Keterbatasan dalam penelitian ini yaitu bahwa responden hanya berjumlah 130 orang dan hanya ditujukan kepada masyarakat Salatiga saja.

2. Hasil pengambilan data melalui kuesioner cenderung berdasar persepsi masing-masing responden. Hal ini menjadi keterbatasan penelitian dikarenakan adanya kemungkinan jawaban yang berbeda antara jawaban responden saat ini dan jawaban di masa yang akan datang. 


\section{DAFTAR PUSTAKA}

Aaker, David 1997. Manajemen Ekuitas Merek. Memanfaatkan Nilai Dari Suatu Merek. Jakarta: Mitra Utama.

Assael, Henry. 1995. Consumer Behavior and Marketing Action. $5^{\text {th }}$ ed. Cincinati. OH: South Western College Publishing.

Durianto, Darmadi., Sugiarto., Widjaja, Anton Wachidin dan Supratikno, Hendrawan, 2003, Invasi Pasar Dengan Iklan yang Efektif. Jakarta : PT. Gramedia Pustaka Utama

Engel, James F. 1995. Perilaku Konsumen. Jakarta : Bina Rupa Aksara.

Ferrinadewi, Erna.2008. Pengaruh Threat Emotion Konsumen dan Brand Trust pada Keputusan Pembelian Produk Susu Anlene Di Surabaya. Jurnal Modus, Vol. 02, No. XII.

Gregory, McChain, N.M. Ray. 2003. Legacy tourism: the search for personal meaning in heritage travel. Tourism Management, Vol. 7, No. 2.

Hair, J.F.., Anderson, R.E., Tatham, R.L., \& William, C.B. (1998). Multivariate data analysis. Five Edition, Prentice Hall.

Handriana, T dan H.F. Yuniar. 2008. Pengaruh Kepuasan Donatur terhadap Future Intentions melalui Kepercayaan dan Komitmen pada Organisasi Nirlaba. Jurnal Bisnis, Vol. 4, No. 5.

Haryanto, J.O. 2008. The Analysis of Intention To Consume Again in Creating Influence Power, Impulsive Buying And Autobiographical Memory. Disertasi: Fakultas Ekonomi Universitas Indonesia.

Howard, J.A., 1994, Buyer Behavior in Marketing Strategy, $2^{\text {nd }}$ ed., New Jersey: Prentice Hall. Hutasoit, Arwin 2004. Iklan Produk Turun Temurun. Marketing, no 09/IV/September Karsono. 2008. Pengaruh Customer Satisfaction dan Trust terhadap Customer Loyalty dengan Switching cost sebagai variable modernisasi. Jurnal Bisnis dan Manajemen Vol 8, No 1.

Khasali, Rhenald., 1992, Manajemen Periklanan: konsep dan Aplikasinya di Indonesia. Jakarta: Pustaka Utama Grafiti.

Kotler, Philip, 2005, Manajemen Pemasaran, Jilid 1. Edisi kesebelas. Klaten : PT. Indeks Kelompok Gramedia..

LaTour, M.S. LaTour, G.M. Zilkhan. 2008. Coke is it: How stories in childhood memories illuminate an icon. Jurnal of Business Research, Vol. 8, No. 9.

Lau, Geok Then dan Sook Han Lee, 1999. Consumer Trust in a Brand and the Link to Brand Loyalty. Journal of Market Focused Management, Vol. 03, No. 01.

Leonard. 2005. Pengaruh Iklan terhadap Minat Beli Studi Empiris pada Handphone Nokia dengan Menggunakan Consumer Decision Model (CDM). Tesis, Universitas Kristen Satya Wacana, Salatiga. 
Maholtra, K. Naresh., 1999, Marketing Research : An Applied Orientation, 3rd.ed. River Prentice Hall

Morgan, R.M. dan Hunt, S.D. 1994. The Commitment Trust Theory of Relationship Marketing. Journal of Marketing, Vol. 07, No. 01.

Prianto, Doni 2004. Iklan Produk Turun Temurun. Marketing, no 09/IV/September

Riana, Gede 2008. Pengaruh Brand Trust Terhadap Brand Loyalty pada Konsumen Air Minum Aqua di Kota Denpasar. Buletin studi ekonomi, Volume 13 no 1

Rusmana, Ricky. 2007. Efektifitas Iklan dengan Pesan Heritage Biskuit Roma dalam Membangun Sikap Konsumen. Skripsi, Fakultas Ekonomi Universitas Kristen Satya Wacana, Salatiga.

Ryan, Natalie Ann. 2002. In Brand We Trust : A Case study of The Trust For International brands in Sweden, Thesis, Graduate Business School, Goteborg University, Elander Novum.

Setyawan, Anton A, dan Ihwan susila, 2004, Pengaruh Service Quality Perception Terhadap Purchase Intention (Studi Empirik Terhadap Konsumen Supermarket), Jurnal Usahawan No 07 Th XXX111

Shimp, Terence A., 2003, Periklanan Promosi Aspek Tambahan Komunikasi Pemasaran Terpadu. Jakarta : Erlangga.

Strizhakova, R.A. Coulter, L.L. Price. 2008. The meaning of branded products: A cross-national scale development and meaning assessment. Jurnal of Marketing Research, Vol.8, No. 05.

Wibowo, Eric. 2009. Analisis Persepsi Konsumen Terhadap Penempatan Produk, Bintang Iklan, Pesan Iklan, dan Iklan Jamu Tolak Angin Sido Muncul Dalam Mempengaruhi Intensi Membeli Konsumen (Study kasus pada Iklan jamu Tolak Angin Sido Muncul Versi orang pintar Agnes Monica). Skripsi, Fakultas Ekonomi Universitas Kristen Satya Wacana, Salatiga.

(http://suaramerdeka.com/2010)

(http:// kompas.com/2010) 